\title{
固体発酵法による無蒸煮コーングリッツからの蒸留酒の製造
}

\author{
佐無田 隆・中島美幸* -太田剛雄・佐伯宏 \\ 佐藤和夫 \\ （国税庁醸造試験所）
}

平成元年 10 月 26 日受理

\author{
Production of Spirits from Uncooked Corn Grits by Solid-state \\ Ethanol Fermentation System \\ Takashi Samuta, Yoshiyuki NaKashima, Takeo OHTA, Hiroshi SAIki, Kazuo Sato, \\ Toshiteru OHBA and Kiyoshi Yoshizawa \\ (National Research Institute of Brewing, 2-6-30 Takinogawa, Kitavku, Tokyo 114)
}

\begin{abstract}
Production of Spirits from Uncooked Corn Grits by Solid-State Ethanol Fermentation System.
Production of spirits from uncooked corn grits by a pilot-scale solid-state ethanol fermentation system (SSEF) was investigated. When the ethanol fermentation is done by SSEF, the recovery of ethanol by circulating $\mathrm{CO}_{2}$ is more effective at high temperature than at lower temperature. Because the corn grits are not heated by the steam, there are high possibilities of contamination by bacteria and molds (fungi) in fermentation. To protect the mash against the contamination, fermentation tests were done by the use of some lactate buffer or lactic acid solutions. Among these liquids, $\mathrm{pH} 3.5,0.2 \mathrm{M}$ lactate buffer was the optimum for fermentation and protection against the contamination. Lactate buffer solution ( $\mathrm{pH} 3.5,0.2 \mathrm{M}$ ) containing saccharifying enzyme and moderately thermophilic yeast (Saccharomyces cerevisiae $1031 \mathrm{R}$ ) was added to the uncooked corn grits in the fermentor and the fermentor was kept at $40^{\circ} \mathrm{C}$. The fermentation was continued for 9 days, and ethanol produced was $399 \mathrm{~g} / \mathrm{kg}$-IDM (initial dry mass). The content of acetaldehyde in the product was about 8 times as high as that in conventional type spirit "shochu".
\end{abstract}

Key words : 固体発酵・無蒸煮発酵・コーングリッツ

\section{緒 論}

中国をはじめアジア各地における伝統的な蒸留酒の製 造方法の 1 つである固体発酵法はアルコールによる発酵 阻害のため生産性は低い'尚が，蒸留残椬が 固体で得られ るため, 蒸留残渣の再利用または処理において利点があ ると考えられる。共同研究者の佐藤ら ${ }^{2 \sim 4)}$ は水分の少な い固体状態のでんぷん質原料に酵母を培養し，不活性な ガスを循環して高濃度のエタノールを含む留液を回収す ると共に, 水分の少ない発酵残渣を得る, 不活性ガス循 環式固体発酵システム (Solid-state ethanol fermentation system, SSEF) を開発した。一方, 省エネルギー 的な観点から無蒸煮原料による発酵法が着目され多くの 報告5 99がある。しかし，いずれも汲水歩合を多くした液 状醪形式の発酵であり，無蒸煮で固体発酵を行った例は

*) 現在 雲海酒造(株)

**) 現在 東京農業大学
報告されていない。固体醪においてアルコールのストリ ッピングを効率的に行うためには温度は高い方が有利で あるが, 原料は無蒸煮であるため殺菌されておらず, 雑 菌が増殖する可能性が高い。またガスによりアルコール をストリッピングするため醪に含まれるアルコール濃度 が低くアルコールによる殺菌効果も低い。したがって, 無蒸煮固体発酵における最大の問題点は安全かつ短期間 に発酵を行う点にある。高温での発酵に適した酵母とし てはタイ国より採取された酵母から $40^{\circ} \mathrm{C}$ で生育, 発酵 ともに良好な酵母として高橋ら ${ }^{10}$ )がスクリーニングした Saccharomyces cerevisiae $1031 \mathrm{R}$ がある。また, 無蒸 煮コーングリッツの糖化に適した酵素として, 永井ら ${ }^{11)}$ は 14 点の酵素剤について比較検討して報告している。 本報では佐藤ら ${ }^{2 \sim 4)}$, 高橋ら ${ }^{10)}$ 及び永井ら ${ }^{111}$ の研究結果を 踏まえ, 高温性酵母 $1031 \mathrm{R}$ を用い, $40^{\circ} \mathrm{C}$ において固体 状態の無蒸煮コーングリッツを酵素剤を用いて糖化し, 安全にアルコール発酵させるための条件について検討し 
佐無田・中島・太田・佐伯・佐藤・大場・吉沢 : 固体発酵法による無蒸煮コーングッッッからの蒸留酒の製造

Table 1 Particle size distribution of corn grits.

\begin{tabular}{c|c|c}
\hline \hline Particle size & Corn grits GB & Corn grits GE \\
\hline (mm) & $($ wt $\%)$ & $($ wt $\%)$ \\
$0.84 \sim 0.30$ & 50.5 & 17.4 \\
$0.30 \sim 0.15$ & 47.0 & 77.1 \\
$0.15 \sim 0.07$ & 2.5 & 5.5 \\
\hline
\end{tabular}

た結果について報告する。

\section{実 験 方 法}

1. 原料

糖化条件の検討にはコーングリッツ GB（日本製粉 (株)製でんぷん価 64.1 , 水分 $12.6 \%(\mathrm{w} / \mathrm{w})$ ) を粉砕し ふるい分けして用いた。仕込試験にはコーングリッツ GE（でんぷん価 75.8 , 水分 $12.2 \%(\mathrm{w} / \mathrm{w})$ ) をとのま ま用いた。・コーングリッッ GB 及び GE の粒度分布は Table 1 のと括りであった。

\section{2. 酵素郕}

Aspergillus niger 起源の液状粗酵素剂 (SUMYZYME $\mathrm{AN}$, 新日本化学工業(株)製) を使用した。これは永井

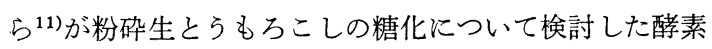
剤の中でグルンース生成量が多く, 無蒸煮発酵に適して いると推定された酵素剂である。

\section{3. 瞵母}

タイ国より採取された酵母から高橋ら ${ }^{10)}$ が高温発酵性 酵母としてスクリーニングした S.cerevisiae $1031 \mathrm{R}$ を 用いた。

\section{4. 小仕込固体発酵}

発酵栓をつけた $500 \mathrm{~m} l$ 容の三角フラスコに乾物換算 で $100 \mathrm{~g}$ のコーングリッツ並びに所定量の酵素剂及び酵 母を混和した乳酸緩衝液を加え, その三角フラスコを $40^{\circ} \mathrm{C}$ の恒温水槽に浸し, $24 \mathrm{hr}$ ごとに重量を測定して発 酵による減少量を求めた。固体醪中の生酸菌の検出は文 献11)記載の方法によった。

\section{5. パイロットプラントによる無蒸薏固体発醏}

パイロットプラントは佐藤らが開発した装置を用い た。同装置の詳細は文献》の通りである。原料はコーン グリッツ $\mathrm{GE}$ を使用し， 1 仕込み $10 \mathrm{~kg}$ (乾物重量 8.87 $\mathrm{kg}$ )または $5 \mathrm{~kg}$ とした。酵母は $1031 \mathrm{R}$ ( $\mathrm{YM}$ 培地 $1 l$ で $48 \mathrm{hr}$ 培養した後集菌したもの), 酵素剂は $1.0 \mathrm{~g} / \mathrm{kg}$ IDM (initial dry mass), 吸水率は $0.8 \mathrm{~kg} / \mathrm{kg}$-IDM で 西った。仕込及後発醅槽内は $40^{\circ} \mathrm{C}$ に保ち, $24 \mathrm{hr}$ 経過 後プラント内のガスを $\mathrm{N}_{2}$ で置換し流速 $25 l / \mathrm{min}$ で循 環した。循環ガスは発酵槽に入る前に $45^{\circ} \mathrm{C}$ の温水と接 触させ加湿した。フルコール蒸気を含んだ 循環ガスは

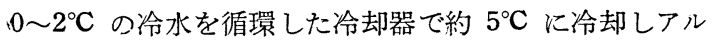

Table 2 Uncooked corn grits for saccharifing test.

\begin{tabular}{c|c|c|c}
\hline \hline No. & $\begin{array}{c}\text { Particle size } \\
(\mathrm{mm})\end{array}$ & $\begin{array}{c}\text { Average diameter } \\
(\mathrm{mm})\end{array}$ & $\begin{array}{c}\text { moisture } \\
(\mathrm{wt} \%)\end{array}$ \\
\hline 1 & $0.84 \sim 0.30$ & 0.57 & 12.6 \\
2 & $0.30 \sim 0.15$ & 0.22 & 12.6 \\
3 & $0.15 \sim 0.11$ & 0.13 & 12.3 \\
4 & $0.11 \sim 0.07$ & 0.09 & 12.3 \\
\hline
\end{tabular}

コールを回収した。アルコールの回収には醪の擋拌が効 果的と考えられたので 1 部の実験では装置内のガス循環 開始と同時に 1 2 rpm で擋拌器を回転した。

\section{6. 分析方法}

グルコースは GOD-4 AA 法 (和光純薬工業(株) グル コースBテストワコー), 酸度及びアルコール分は国税 庁所定分析法 ${ }^{12}$ によった。留液の低沸点成分は $2 \mathrm{~m}$ のガ ラスカラムに 10\% PEG 600 を充填し，カラム温度 $60^{\circ} \mathrm{C}$ としてガスクロマトグラフィーによった。

\section{実験結果及び考察}

\section{1. 発酵条件の設定}

（1）無蒸煮コーングリッツの糖化に及ぼす酵素剤量 及び水分の影鐿

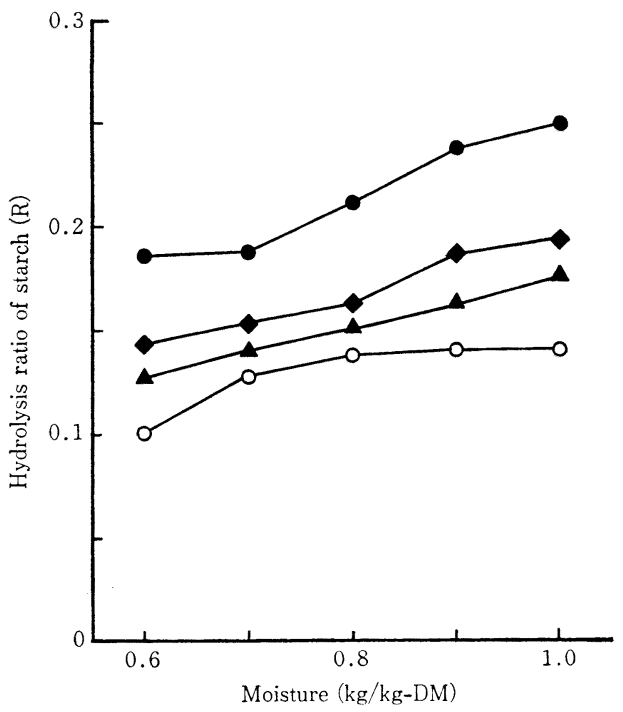

Fig. 1 Effects of enzyme amount and moisture on saccharification of uncooked corn grits. The particle size of the corn grits was $0.15 \sim 0.30 \mathrm{~mm}$ in diameter(No. 2 in Table 2). Lactate buffer ( $\mathrm{pH} 4.3$, $0.1 \mathrm{M}$ ) containing enzyme was added to the corn grits, and it was kept at $40^{\circ} \mathrm{C}$ for $24 \mathrm{hr}$. The vertical axis is defined by Eq. (1).

$\begin{array}{ll}\text { Symbols } & \text { Amount of Enzyme } \\ & 5.0 \mathrm{~g} / \mathrm{kg}-\mathrm{IDM} \\ & 1.0 \\ 0 & 0.5 \\ & 0.1\end{array}$


コーングリッツ GB を粉砕し Table 2 のようにふる い分けして糖化試験の試料とした。粒径 $0.15 \sim 0.30 \mathrm{~mm}$

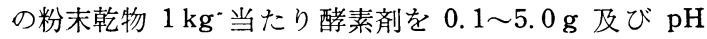
$4.3,0.1 \mathrm{M}$ 乳酸緩衝液 $0.6 \sim 1.0 \mathrm{~kg}$ を加え $40^{\circ} \mathrm{C}$ で 24 $\mathrm{hr}$ 反応させ，生成したグルコースの量を測定した。結 果を Fig. 1 に示した。Fig. 1 に扣いて横軸は乾物 $1 \mathrm{~kg}$ 当たりの吸水量 $(\mathrm{kg} / \mathrm{kg}-\mathrm{DM})$, 縦軸はグルュースまで 分解されたでんぷんの，原料中のでんぷんに占める割合 $R$ であり Eq.（1）であらわされる。

$$
R=0.90 \mathrm{G} / C S
$$

Eq. (1)においてC は試料の重量 $(\mathrm{g}), S$ は試料の でんぷん価 $/ 100, G$ は糖化後の反応物中のグルコース （g）である。酵素剤の添加量が $0.1 \mathrm{~g} / \mathrm{kg}-\mathrm{DM}$ と少ない 場合を除き酵素剂添加量が多い汇ど，また吸水率が高い ほど反応率は高かった。吸水率 $1.0 \mathrm{~kg} / \mathrm{kg}-\mathrm{DM}$ (drymass）ではベタベタした状態となり固体発酵醪としては $0.8 \sim 0.9 \mathrm{~kg} / \mathrm{kg}-\mathrm{DM}$ が適当と考えられたので以後の実 験に拈いては吸水率 $0.8 \mathrm{~kg} / \mathrm{kg}-\mathrm{DM}$ を標準とした。吸 水率 $0.8 \mathrm{~kg} / \mathrm{kg}-\mathrm{DM}$ において, 酵素剂の添加量は多い ほど有利であるが, 添加量 $1 \mathrm{~g} / \mathrm{kg}-\mathrm{DM}$ と $5 \mathrm{~g} / \mathrm{kg}-\mathrm{DM}$ を比較すると糖化 $24 \mathrm{hr}$ 後の後者の反応率は前者の 1.3 倍にすぎないことから以後の実験に拈いては酵素剤の添

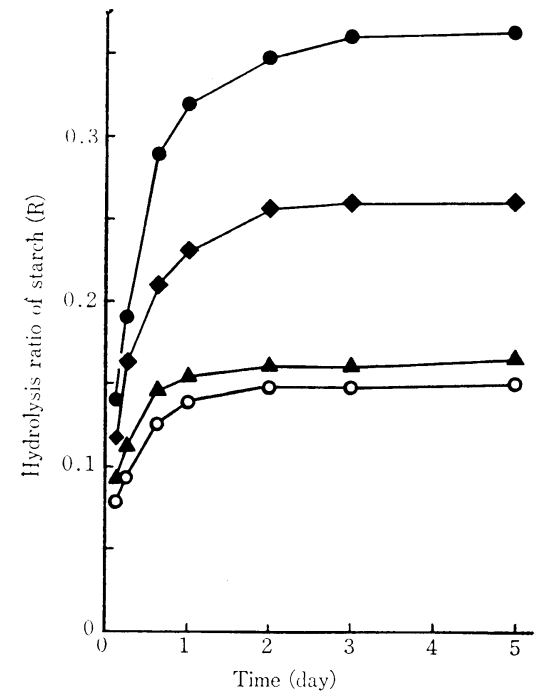

Fig. 2 Time course of starch hydrolysis in corn grits.

Lactate buffer ( $\mathrm{pH} 4.3,0.1 \mathrm{M})$ containing enzyme $(1.0 \mathrm{~g} /$ $\mathrm{kg}-\mathrm{DM}$ ) was added to the corn grits. The liquid-ratio to corn grits was $0.8 \mathrm{~kg} / \mathrm{kg}-\mathrm{DM}$. The reaction of hydrolysis was done at $40^{\circ} \mathrm{C}$.

Symbols Average particle diameter

- $0.09 \mathrm{~mm}$

$-\quad 0.13$

$\Delta \quad 0.22$

O $\quad 0.57$

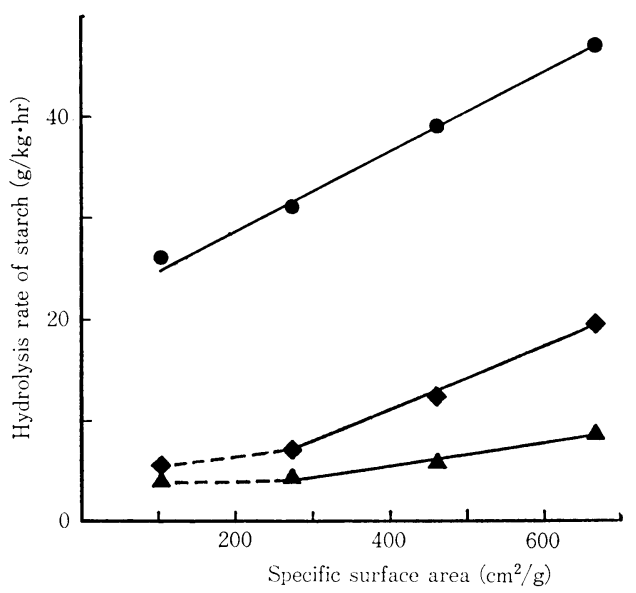

Fig. 3 Relationship beteeen the hydrolysis rate of starch and the specific surface area of corn grits.

Specific surface area and hydrolysis rate of starch were calculated from the data of Fig. 2.

Symbols Saccharifying time.

\begin{tabular}{l}
$0 \sim 3 \mathrm{hr}$ \\
$\quad \quad 3 \sim 6 \mathrm{hr}$ \\
\hline
\end{tabular}

4. $6 \sim 15 \mathrm{hr}$

加量は $1 \mathrm{~g} / \mathrm{kg}-\mathrm{DM}$ を標準とした。

（2）無蒸煮コーングリッツの糖化に及ぼす粒径の 影響

椎木ら ${ }^{91}$ は 1 次醪に米楼, 2 次醪に無蒸煮の大麦を用 いた焼酎の仕込試験において，粉研した大麦では発酵が 促進されたと報告している。一方，水溶液中にでんぷん 質原料を懸濁して糖化反応を行う場合，アミラーゼので んぷんへの吸着量と原料の表面積とは必ずしも比例しな いが，生でんぷん分解の容易さとアミラーゼのでんぶん

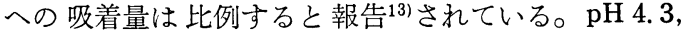
$0.1 \mathrm{M}$ 乳酸緩衝液を用いて吸水率 $0.8 \mathrm{~kg} / \mathrm{kg}-\mathrm{DM}$, 酵素 剂 $1.0 \mathrm{~g} / \mathrm{kg}-\mathrm{DM}$ とし, 反応温度 $40^{\circ} \mathrm{C}$ で生成したグル コースを経時的に測定した結果を Fig. 2 に示した。

Fig. 2 の横軸は反応時間 (day), 縦軸ではでんぷんの反 応率 $R$ である。粒径の小さなものが初期の糖化速度は大 きく, $120 \mathrm{hr}$ 経過後の反応率も高かった。Fig. 3 に糖化 速度と表面積の関係を示した。Fig. 3 の横軸はコーング リッツ粒の比表面積 $\left(\mathrm{cm}^{2} / \mathrm{g}\right)$, 縦軸はでんぷんの糖化速 度（g-でんぷん/(kg-でんぷん・hr)）である。糖化反応 初期 ( $0 \sim 3 \mathrm{hr}$ の平均值) には両者の関係はほぼ直線と なり糖化反応初期には糖化速度はコーングリッツ粒の表 面積に比例することを示している。固体無蒸煮コーング リッツの場合，コーングリッツに酵素剤を含む水溶液を 加えるが，水は全部吸収されるので流動する水はない状 態であるため, 酵素剤はコーングリッツの表面に吸着さ 
れ，反応速度は原料粒の表面積に比例するものと推察さ れる。したがって、コーングリッツの粒径は糖化反応か らは小さい方が有利であるがこの装置では通風性も必要 なのでパイロットプラントではコーングリッツ GE を 使用することとした。

（3）無蒸煮コーングリッツの糖化に及ぼす $\mathrm{pH}$ 及 び緩衝液濃度の影響

粉砕した試料 No.2 (Table 2) を用いて, pH 3.0 4.5 , 緩衝液濃度 $0.1 \sim 0.5 \mathrm{M}$ とし, $40^{\circ} \mathrm{C}, 24 \mathrm{hr}$ 反応さ せて $R$ を测定したところ, 実験の範囲で $R$ は $0.15 \sim 0.16$ であって,この条件では $\mathrm{pH}$ 及び緩衝濃度の糖化反応へ の影響は小さいと推察された。

（4）酵母 $1031 \mathrm{R}$ の増殖に及ぼす $\mathrm{pH}$ 及び緩衝液濃 度の影響

無蒸煮発酵では加熱工程を経ていないため乳酸菌・枯 草菌等の細菌類のほか糸状菌等の原料中の微生物 (以下 雑菌という）が発酵に影響する可能性が高い。清酒醸造 において酒母及び醪が開放発酵により安全に醸造できる 理由の 1 つとて乳酸の抗菌性の巧みな利用 ${ }^{15}$ があげ られる。固体発酵においても乳酸酸性下で発酵を行ら方 法は有力な方法と考えられる。しかし，清酒酵母は乳酸 $1.5 \%$ を含さ合成培地での静置培養では生育は著しく抑

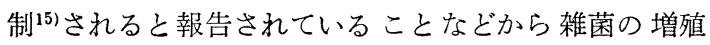
を防ぐことのみを目的として $\mathrm{pH}$ を著しく低くするこ とはできない。一方清酒の酒母, 醪及び焼酎醪は滴定酸 度により管理され実効が上がっている。 $\mathrm{pH}$ は一定にし で緩衝液の濃度を変えると滴定酸度を変えることができ るから, 乳酸緩衝液の $\mathrm{pH}$ 及び濃度の組合せを変える ことにより雑菌の増殖を抑制することを試みた。なお, エタノールが存在する乳酸酸性下で生存する雑菌類とし ては乳酸菌が主であると考えられたので，以下の実験に おいては生酸菌を検出し, 雑菌污染のメルクマールとし た。濃度 $0.1 \sim 0.4 \mathrm{M}$ の乳酸緩衝液を用いて $\mathrm{pH} 3.0$

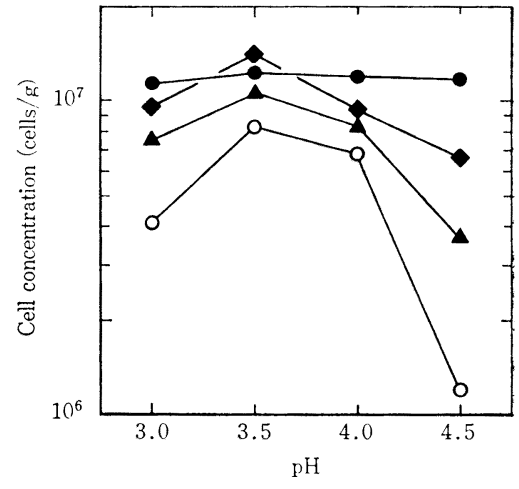

Fig. 4 Effects of $\mathrm{pH}$ and the concentration of lactate buffer on growth of S.cerevisiae $1031 \mathrm{R}$.

YM-medium containing $0.1 \sim 0.4 \mathrm{M}$ lactate buffers were used for cultivation of S.cerevisiae $1031 \mathrm{R}$. Cultivation was done at $40^{\circ} \mathrm{C}$ for 7 days. Cell concentration was measured by a spectrophotometer at $\mathrm{OD}^{660}$.

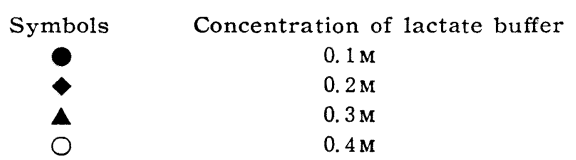

4.5 の $\mathrm{YM}$ 培地（酵母エキス $0.3 \mathrm{~g}$, 麦芽エキス $0.3 \mathrm{~g}$ ， ポリペプトン $1.0 \mathrm{~g}$, グルュース $5.0 \mathrm{~g}$, 緩衝液 $100 \mathrm{ml}$ ) を調整し，その $10 \mathrm{~m} l$ に高温性酵母 1 白金耳を接種した 後, $40^{\circ} \mathrm{C}$ で 7 日間静置培養し酵母数を測定した結果を Fig. 4 に示した。酵母数は吸光度 $\left(\mathrm{OD}^{660}\right)$ により測定し た。乳酸緩衝液 $0.1 \mathrm{M}$ の場合, 実験の範囲で酵母の増 殖量は $\mathrm{pH}$ の影響をほとんど受けなかった。緩衝液の濃 度が高くなると増殖量は減少する傾向があり,また，緩 衝液が同一濃度の場合, $\mathrm{pH} 3.5$ のとき増殖量は最大と なった。

\section{2. 小仕込試験による発酵条件の検討}

パイロットプラントでの発酵試験に先立ち, $500 \mathrm{ml}$ 容

Table 3 Properties of solution added to uncooked corn grits, and the effects of those solution on $\mathrm{CO}_{2}$ evolution and cell concentration of acid-producing bacteria in solid state mash.

\begin{tabular}{c|c|c|c|c}
\hline \hline \multicolumn{2}{|c|}{ Added solutions to uncooked corn grits } & $\begin{array}{c}\mathrm{CO}_{2} \\
\text { evolution } \\
\text { (g/100 g-IDM) }\end{array}$ & $\begin{array}{l}\text { Acid-producing } \\
\text { bacteria } \\
\text { (cells/g-mash) }\end{array}$ \\
\hline pH & concentration & $\begin{array}{c}\text { acidity } \\
(\mathrm{m} l-0.1 \mathrm{~N} \cdot \mathrm{NaOH})\end{array}$ & 6.3 & 10 \\
3.0 & 0.1 M-lactate buff. & 5.4 & 4.9 & $1.5 * 10^{6}$ \\
3.5 & 0.1 M-lactate buff. & 3.7 & 6.1 & $2.5 * 10^{6}$ \\
3.5 & 0.1 M-lactate buff. & 2.0 & 6.3 & 0 \\
3.8 & 0.2 M-lactate buff. & 7.5 & 6.0 & $2.0 * 10^{4}$ \\
4.0 & 0.2 M-lactate buff. & 5.7 & 6.1 & $6.0 * 10^{4}$ \\
3.8 & 0.2 M-lactate buff. & 4.3 & 7.0 & 80 \\
4.0 & 0.3 M-lactate buff. & 8.3 & 5.3 & 130 \\
2.5 & $0.7 \%$ lactic acid & 6.5 & 6.1 & 750 \\
2.4 & $1.0 \%$ lactic acid & 5.5 & 6.3 & 50 \\
\hline
\end{tabular}


佐無田・中島・太田・佐伯・佐藤・大場・吉沢 : 固体発酵法による無蒸煮コーングリッツからの蒸留酒の製造

Table 4 Conditions of solid-state fermentation by use of uncooked corn grits.

\begin{tabular}{|c|c|c|c|c|c|c|}
\hline \multirow{2}{*}{$\begin{array}{c}\text { Materials } \\
\text { Run }\end{array}$} & \multicolumn{5}{|c|}{ Uncooked } & \multirow{2}{*}{ Cookeda) } \\
\hline & 1 & 2 & 3 & 4 & 5 & \\
\hline Temperature $\left({ }^{\circ} \mathrm{C}\right)$ & 40 & 40 & 40 & 40 & 40 & 40 \\
\hline Strain of yeast & $1031 \mathbf{R}$ & $1031 \mathrm{R}$ & $1031 \mathrm{R}$ & $1031 \mathrm{R}$ & $1031 \mathrm{R}$ & $1031 \mathrm{R}$ \\
\hline Saccharifying enzymeb) & S-AN & S-AN & S-AN & S-AN & S-AN & $G-100$ \\
\hline Running time (day) & 10 & 10 & 11 & 17 & 9 & 17 \\
\hline \multirow{2}{*}{$\begin{array}{l}\text { Material }(\mathrm{kg}) \\
\text { Added solutionc) }\end{array}$} & 10 & 10 & 10 & 10 & 5 & 10 \\
\hline & buffer & acid & buffer & buffer & buffer & buffer \\
\hline concentration & $0.1 \mathrm{M}$ & 1.0 vol $\%$ & $0.1 \mathrm{M}$ & $0.1 \mathrm{M}$ & $0.2 \mathrm{M}$ & $0.1 \mathrm{M}$ \\
\hline \multirow{2}{*}{ Agitation (rpm) } & 4.0 & 2.4 & 3.0 & 3.0 & 3.5 & 4.0 \\
\hline & $1 \sim 2$ & $1 \sim 2$ & $1 \sim 2$ & $3 /$ dayd & & $1 \sim 2$ \\
\hline
\end{tabular}

a) Date of cooked corn grits was obtained using the same solid-state fermention system by SATo et $a 1^{3)}$.

b) Saccharifying enzyme, S-AN : SUMYZYME AN, G-100: Gluc-100.

c) Added solution, buffer : lactate buffer, acid: lactic acid.

d) Mash was agitated for 1 minute at 9 a.m., 12 a.m. and 5 p.m.

わ三角フラスコを仕込容器として回分小仕込試験により 発酵条件の検討を行った。コーングリッツ GE を原料と し, 吸水率は $0.8 \mathrm{~kg} / \mathrm{kg}-\mathrm{I} \mathrm{DM}$, 酵母 は $1031 \mathrm{R}$, 酵素 版添加量は $1.0 \mathrm{~g} / \mathrm{kg}-\mathrm{IDM}$ とし, $\mathrm{pH} 3.0 \sim 4.0$, 濃度 $0.1 \sim 0.3 \mathrm{M}$ の乳酸緩衝液及び $0.7 \%(\mathrm{v} / \mathrm{v})(\mathrm{pH} \mathrm{2.5}) \sim$ $1.0 \%(\mathrm{v} / \mathrm{v})(\mathrm{pH} 2.4)$ の乳酸水溶液を汲み水の代わりに 使用した。発酵終了時の 各仕込み容器の炭酸ガス減量 (g/kg-IDM) 及び生酸菌数を Table 3 に示した。同じ濃 度であれば $\mathrm{pH}$ が低い方が生酸菌数は少なく, 同じ $\mathrm{pH}$ であれば濃度が高い方が生酸菌の数は少なかった。 Fig. 4 及び Table 3 の結果は, pH を著しく低くしなく ても酵素剂の最適 $\mathrm{pH}$ に少いて緩衝液の濃度を高くす ると生酸菌の增殖を抑制することができるが，緩衝液の 濃度により酵母の增殖も影響を受けることを示してい る。生酸菌数及び炭酸ガス減量から次の 3 種類の液体が 仕込み水として使用の可能性があると考兄られた。

(1) $1.0 \%(\mathrm{v} / \mathrm{v})$ 乳酸

(2) $\mathrm{pH} 3.0,0.1 \mathrm{M}$ 乳酸緩衝液

(3) $\mathrm{pH} 3.5,0.2 \mathrm{M}$ 乳酸緩衝液

3. パイロットプラントによる固体発酵

前項に記載した(1)(2)(3)の作藤ら゙)が蒸煮したコー ングリッッについて行った条件に近い $\mathrm{pH} 4.0,0.1 \mathrm{M}$ 乳酸緩衝液の 4 種類の液体を使用してパイロットプラン トによる無蒸煮固体発酵を行った。発酵試験は 5 回行っ たが，その実験条件は Table 4 にまとめて示した。

(1) $\mathrm{pH} 4.0,0.1 \mathrm{M}$ 乳酸緩衝液（擋拌 $1 \sim 2 \mathrm{rpm}$.

Run 1) 発酵経過を Fig. 5 に示した。アルコール回収 開始直後に腐造状態となり酸臭が強く，2 日目からは留 液の酸度が 2 以上となった。アルコール収得量も 9 日間 で $84 \mathrm{~g} / \mathrm{kg}-\mathrm{IDM}$ と低かった。

(2) $1.0 \%(\mathrm{v} / \mathrm{v})$ 乳酸 $(\mathrm{pH} 2.4$, 擋拌 $1 \sim 2 \mathrm{rpm}$. Run 2) 発酵経過を Fig. 5 に合わせて示した。腐造と
はならなかったが安定した発酵を持続することはできな かった。

(3) $\mathrm{pH} 3.0,0.1 \mathrm{M}$ 乳酸緩衝液（擋拌 $1 \sim 2 \mathrm{rpm}$. Run 3） 発酵経過を Fig. 5 に合わせて示した。腐造と はならなかったが，4日目以後は留液のアルコール分は

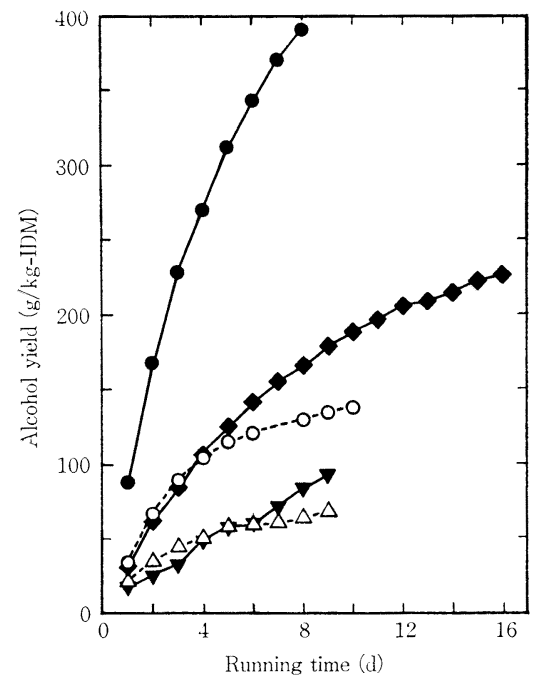

Fig. 5 Time course of the solid state fermentation of uncooked corn grits.

The solid state fermentations using pilot scal fermentor were done at $40^{\circ} \mathrm{C}$. Lactate buffer or lactic acid solution containing the saccharifying enzyme and $S$. cerevisiae $1031 \mathrm{R}$ were added to the uncooked corn grits. The liquid-ratio to the corn grits was $0.8 \mathrm{~kg} / \mathrm{kg}$ IDM.

\begin{tabular}{cccc} 
Symbols & \multicolumn{2}{c}{ Liquid } & Run \\
& $\mathrm{pH}$ & Concentration & \\
$\triangle$ & 4.0 & $0.1 \mathrm{M}$ lactate buffer & 1 \\
$\nabla$ & 2.4 & 1.0 vol. \% lactic acid & 2 \\
$\bigcirc$ & 3.0 & $0.1 \mathrm{M}$ lactate buffer & 3 \\
$\bullet$ & 3.0 & $0.1 \mathrm{M}$ lactate buffer & 4 \\
& 3.5 & $0.2 \mathrm{M}$ lactate buffer & 5
\end{tabular}


佐無田・中島・太田・佐伯・佐藤・大場・吉沢 : 固体発酵法による無蒸煮コーングリッッからの蒸留酒の製造

Table 5 Results of solid-state fermentation by use of uncooked corn grits.

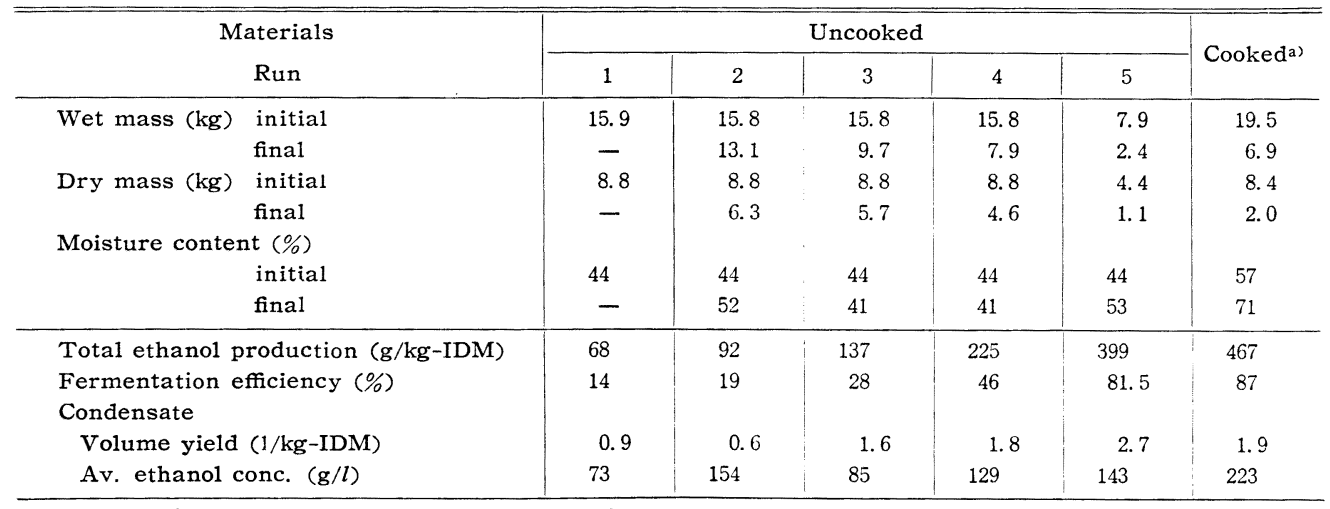

a) Data of cooked corn grits was obtained using same solid-state fermentation system by SATO et al ${ }^{3)}$.

10\%（v/v）以下となった。実験終了時 Run 1〜3 は基質 を支える発酵槽下部の金網の目詰まりが著しく，擋拌の 影響と考えられた。

(4) $\mathrm{pH} 3.0,0.1 \mathrm{M}$ 乳酸緩衝液 (擋拌 $1 \sim 2 \mathrm{rpm}$ で 1 分間， 1 日 3 回·Run 4) Run 3 と同じ条件で擋拌は 朝，昼及び夕刻に $1 \sim 2 \mathrm{rpm} て ゙ 1$ 分間だけ擋拌した。発 酵経過を Fig. 5 に合わせて示した。16 日間発酵を続け たが腐造とはならなかった。Run 2 及び 3 に比べ順調に 発酵し， 7 日目までは留液量は $1 l /$ day 以上であったが， 8 日目より徐々に留液量及びアルコール収得量は減少し た。実験終了時発酵槽下部の基質を支える金網の目詰ま りが著しかった。液状醪と異なり，固体状醪の場合は流 動性がないため擋拌により醪容器の底部に過大な力がか かり，醪を支えている金網の目詰まりが起こると推察さ れた。

（5） $\mathrm{pH} 3.5 ， 0.2 \mathrm{M}$ 乳酸緩衝液（撹拌なし·Run 5) Run 1〜4 の結果, 乳酸緩衝液は $\mathrm{pH} 3.0 ， 0.1 \mathrm{M}$ であれ ば安全に発酵できるが， $\mathrm{pH}$ が低すぎるためか発酵がや や緩慢であること，また，撹拌はしないほらがよいとい らことがわかった。そこで, 各種の緩衝液 (Fig. 4) に拈 いて酵母の増殖性がよく, 小仕込の固体醪 (Table 3) に 打いて生酸菌菌数の少なかった $\mathrm{pH} 3.5,0.2 \mathrm{M}$ 乳酸緩 衝液を用いて発酵試験を行った。発酵経過は Fig. 5 に 合わせて示した。 Run 1〜4 に比べ安定した発醏状態と なった。1 日当たりのアルコールの収得量 ( $\mathrm{g} / \mathrm{kg}-\mathrm{IDM})$ 及び留液中のアルコール分はストリッピング開始 1 日目 がそれどれ $87.7 \mathrm{~g} / \mathrm{kg}-\mathrm{IDM}, 27.7 \%(\mathrm{w} / \mathrm{w})$ と最も高く 以後徐々に低下した。 8 日目にアルコール収得量の累計 は $391 \mathrm{~g} / \mathrm{kg}-I D M$ となり, 留液中のアルコール分は $6.6 \%(\mathrm{w} / \mathrm{w})$ と低下したので発酵終了とした。発酵終了 時の醪の水分は $53.4 \%(\mathrm{w} / \mathrm{w})$ であった。この醪を発酵 槽に充填したまま加湿せずに内部のガスを $24 \mathrm{hr}$ 循環し たところ醪の水分は $29.2 \%(\mathrm{w} / \mathrm{w})$ まで低下した。この
乾燥操作によりアルコール分 $3.5 \%(\mathrm{w} / \mathrm{w})$ の留液 865 $\mathrm{m} l$ とサラサラした粉状の蒸留残椬 $1.55 \mathrm{~kg}$ が得られ た。なお, 乾燥後の蒸留残渣からはアルコール分は検出 されなかった。また, 加湿器中の液体はアルコール分 $0.2 \%(\mathrm{v} / \mathrm{v}), 4825 \mathrm{ml}$ であった。

Run 1〜5 の実験結果を Table 5 に示した。同表には

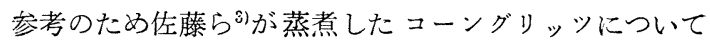
行った結果を合わせて示した。実験した無蒸募固体発酵 の内, Run 5 は発酵日数 9 日間で留液として $397 \mathrm{~g} / \mathrm{kg}$ IDM (乾燥中の留出液を含む) のアルコールを収得する ことができ Run 1〜4に比べ格段に優れていた。原料 $1 \mathrm{t}$ 当たりの留液中の純アルコール収得量として算出する と $439 \mathrm{l} / \mathrm{t}$ で, コーングリッツを原料とした本格焼酎の アルコール収得率 $420 \sim 440 \mathrm{l} / \mathrm{t}^{16)}$ と同水準であり固体醪 は正常に発酵したものと推察された。対でんぷんのアル コール収率は理論值の $81.5 \%$ であって, 佐藤ら ${ }^{3}$ が行 った蒸煮固体発酵（発酵日数 15 日間）のアルコール収 量 $467 \mathrm{~g} / \mathrm{kg}-\mathrm{IDM}$ (アルコール収率 $87 \%$ ) に比較すると やや低かったが，短期間に安全に発酵させるとい5目的 は達せられたと判断した。

4. 無蒸煮コーングリッツを原料とした固体発酵法に よる蒸留酒の特徵

発酵が順調であった Run 5 について，発酵期間中の 留液の酸度, $\mathrm{pH}$ 及び低沸点成分含量を分析した結果を Table 6 に示した。参考として従来の方法で造られた市 販とうもろこと焼酎（減压及び常圧蒸留）について行っ た分析值及び佐藤らの蒸煮固体発酵法による蒸留酒の分 析值 ${ }^{4)}$ を合わせて示した。Table 5 の低沸点成分の分析值 はアルコール分 $25 \%(\mathrm{v} / \mathrm{v})$ 当たりに換算した值である。 本実験の留液の酸度は, ガス循環 1 日目が 0.7 であった のに対し発酵期間中徐々に増加し, 発酵終了時の 8 日目 は 2.8 , 留液全部を混和した後の酸度は 1.6 であった。 これは蒸留酒としては酸度は高いレベルであると考えら 
佐無田・中島・太田・佐伯・佐藤・大場・吉沢 : 固体発酵法による無蒸煮コーングリッツからの蒸留酒の製造

Table 6 Results of analysis of the SSEF products (Run 5).

\begin{tabular}{|c|c|c|c|c|c|c|c|c|}
\hline Fermentation method & \multicolumn{5}{|c|}{ SSEF (Run 5) } & \multirow{3}{*}{$\begin{array}{l}\text { SSEF* } \\
\text { cooked }\end{array}$} & \multirow{3}{*}{$\begin{array}{c}\text { Shochu A** } \\
\text { cooked }\end{array}$} & \multirow{3}{*}{$\frac{\text { Shochu } \mathrm{B}^{* *}}{\text { cooked }}$} \\
\hline Material & \multicolumn{5}{|c|}{ uncooked } & & & \\
\hline Fermentation time (days) & 1 & 3 & 5 & 7 & mixture & & & \\
\hline Acidity (ml) & 0.7 & 1.1 & 1.5 & 2.1 & 1.6 & - & 0.4 & 0.3 \\
\hline Volatile components (ppm) & & & & & & & & \\
\hline Acetaldehyde & 90 & 72 & 110 & 160 & 84 & - & 10 & 10 \\
\hline EtOAc & 67 & 62 & 51 & 59 & 61 & 163 & 65 & 58 \\
\hline$n-\mathrm{PrOH}$ & 204 & 139 & 152 & 166 & 162 & 47 & 130 & 90 \\
\hline$i-\mathrm{BuOH}$ & 196 & 240 & 257 & 345 & 255 & 200 & 219 & 210 \\
\hline$i$-AMOH & 821 & 497 & 600 & 639 & 613 & 429 & 747 & 455 \\
\hline Total higher alcohols & 1221 & 876 & 1009 & 1150 & 1030 & 743 & 1096 & 755 \\
\hline Ratio of higher alcohols & & & & & & & & \\
\hline $\mathrm{B} / \mathrm{P}$ & 0.96 & 1.73 & 1.69 & 2.08 & 1.58 & 4.29 & 1.68 & 2.33 \\
\hline $\mathrm{A} / \mathrm{P}$ & 4.02 & 5.57 & 3.95 & 3.85 & 3.78 & 9.22 & 5.74 & 5.05 \\
\hline $\mathrm{A} / \mathrm{B}$ & 4. 18 & 2.07 & 2.33 & 1.85 & 2.40 & 2.15 & 3.41 & 2.17 \\
\hline
\end{tabular}

*) Data of cooked corn grits was obtained using the same solid-state fementationsystem by SATo et al4).

**) Shochu A and B are conventional type in the commercial sprits which were distilled at the atmospheric and the reduced pressure, respectively.

れるが，高橋ら ${ }^{10}$ が同酵母 $1031 \mathrm{R}$ を用いて行った焼酎 の小仕込試験の場合も対照酵母 SH-4 の酸度 0.89 に詨 し酸度 1.38 と酸度が高い傾向が報告されており，この 酵母の性質ではないかと考えられる。低沸点成分では acetaldehyde が従来法による焼酎に比べ 8 倍も多かっ た。また acetaldehyde は酸度と同様に発酵期間中徐々 に増加した。菅間ら ${ }^{17)}$ 女藷を原料として製造した固体 発酵による蒸留酒においても acetaldehyde が著しく多 かったと報告しているがその原因についてはさらに検討 したい。酢酸エチル及び高級アルコール（n-PrOH， $i$ $\mathrm{BuOH} ， i-\mathrm{AmOH})$ については従来法と大きな差は見ら れなかったが, 佐藤ら゙)が行った蒸煮固体発酵法による 製品と比較すると酢酸エチルが少なく, 上記 3 種類の高 級アルコールの含量が高かった。

5 人の審査員により官能審査を行った結果, 香りに関 しては, アルデヒド臭, 原料 (とらもろこし) 臭, 粉臭 等の指摘があり，発酵期間後期になるにつれて評点が悪 くなる傾向があった。味については, 苦い, らすい等の 指摘があった。総合的に従来法による焼酎と比較する 之, 原料由来の香り及び acetaldehyde に起因する香り が強い反面, 味は軽くやや物足りなさが感じられるとい ら特徴があった。

\section{要 䄪}

1. 無蒸煮のコーングリッツを原料とし炭酸ガスによ りストリッピングを行う固体発酵は温度が高い方がアル コールの回収には有利であるが腐造しやすいため, 安全 にかつ短期間に発酵を行ら条件について検討した。

その結果 $\mathrm{pH} 3.5,0.2 \mathrm{M}$ 乳酸緩衝液は無蒸煮コーン グリッツの糖化及び高温性酵母 $1031 \mathrm{R}$ の増殖への影響
が少なく，生酸菌の増殖を抑制するのに最適であること がわかった。

2. $\mathrm{pH} 3.5,0.2 \mathrm{M}$ 乳酸緩衝液を汲み水の代わりに 使用し固体発酵を行った結果 9 日間でコーングリッツ $1 \mathrm{~kg}$ 当たりアルコール $432 \mathrm{ml}$ を収得することができた。

3. 成分的に従来法による焼酎と比較すると acetaldehyde が著しく多く, 官能審査の結果では原料由来の 香り及び acetaldehyde に起因すると考えられる香りが 強かった。

最後に臨み, 酵素剤及び高温発酵性酵母について貴重 な御助言を賜りました当所第 4 研究室長高橋康次郎博士 （現札幌国税局鑑定官室長）に深謝いたします。

\section{文献}

1）大谷惣助: 醸協, 68, (6) 423 (1973)

2) K. SATo, K. NAKAmURA, S. SATo : Biotechnol., Bioengi., 27, 1313 (1985)

3) KazUo Sato, Shin-Iti Mimazaki, NobUya MATSUMOTO, KIYOSHI YOSHIZAWA KIN-ITI NAKAMURA : J. Ferment. Technol., 66, 173 (1988)

4）佐藤和夫, 宮崎伸一, 吉沢 淑 : 醸協, 83, (8) 559 (1988)

5）山崎何恵, 上田誠之助, 島田豊明 : 酸協, 21, 83 (1963)

6）熊谷知栄子, 宮入正法, 黄正財, 鈴木逸郎, 田中 利雄, 秋山裕一: 醱酵工学, 60, 77 (1982)

7) 椎木 敏, 岩野君雄, 三上重明, 福田 清治 : 醸 協, 82, (1) 60 (1986)

8) 能勢 晶, 岩野君雄, 椎木 敏, 平井光雄, 吉沢 淑：醱酵工学, 66, 469 (1988)

9) 椎木 敏, 岩野君雄, 三上重明, 清水慎一郎 : 醸 協，82，（9）651 (1987)

10）高橋康次郎, 緒方新一郎, 吉沢 淑, 中村欽一, 
佐無田・中島・太田・佐伯・佐藤・大場・吉沢 : 固体発酵法による無蒸煮コーングリッツからの蒸留酒の製造

PRADIT KARUWANNA, JAROON KUMNUUANA: 醸協, 81, (2) 124 (1986)

11）永井英雄, 高橋康次郎, 吉沢 淑 : 醸協, 81, (4) 268 (1986)

12）村上英也監修: 国税庁所定分析法, 日本醸 造 協 会, (1974)

13）上田誠之助：澱粉科学, 21, 210 (1974)

14）岩野君夫, 三上重明, 大石篤志, 椎木 敏 : 醸
協, 82，(12) 913 (1987)

15）福井三郎, 谷 喜雄 : 清酒酵母の研究, p. 89 , 清 酒酵母研究会 (1980)

16）角田太一郎，西谷尚道：焼酎醸造技術， p. 6 , 日 本醸造協会 (1985)

17）菅間誠之助, 西谷尚道, 山口征夫：醸協, 74, (10) 692 (1979) 